\title{
Primary Membranous Glomerulonephritis: The Role of Serum and Urine Biomarkers in Patient Management
}

\author{
Sadiq Mu'azu Maifata ${ }^{1,2,3}{ }^{(}$, Rafidah Hod ${ }^{2}$, , Fadhlina Zakaria ${ }^{4}$ and Fauzah Abd Ghani ${ }^{1, *}$ \\ 1 Histopathology Unit, Department of Pathology, Faculty of Medicine and Health Science, Universiti Putra \\ Malaysia, Serdang, Selangor 43400, Malaysia; teemoh87@gmail.com \\ 2 Physiology Unit, Department of Anatomy, Faculty of Medicine and Health Science, Universiti Putra \\ Malaysia, Serdang, Selangor 43400, Malaysia; rafidahhod@upm.edu.my \\ 3 Department of Physiology, Faculty of Basic Medical Science, College of Medicine, Federal University Lafia, \\ Lafia, Nasarawa 950102, Nigeria \\ 4 Nephrology Unit, Department of Medicine, Faculty of Medicine and Health Science, Universiti Putra \\ Malaysia, Serdang, Selangor 43400, Malaysia; n_fadhlina@upm.edu.my \\ * Correspondence: fauzah@upm.edu.my; Tel.: +60-13-6277576
}

Received: 17 October 2019; Accepted: 31 October 2019; Published: 1 November 2019

\begin{abstract}
The detection of phospholipase $\mathrm{A} 2$ receptor $\left(\mathrm{PLA}_{2} \mathrm{R}\right)$ and thrombospondin domain containing 7A THSD7A among primary membranous glomerulonephritis (MGN) patients transformed the diagnosis, treatment monitoring, and prognosis. Anti-PLA $\mathrm{P}_{2} \mathrm{R}$ can be detected in $70-90 \%$ of primary MGN patients while anti-THSD7A in 2-3\% of anti-PLA ${ }_{2} \mathrm{R}$ negative primary MGN patients depending on the technique used. Serum and urine samples are less invasive and non-invasive, respectively, and thus can detect the presence of anti-PLA $\mathrm{A}_{2} \mathrm{R}$ and anti-THSD7A with higher sensitivity and specificity, which is significant in patient monitoring and prognosis. It is better than exposing patients to a frequent biopsy, which is an invasive procedure. Different techniques of detection of $\mathrm{PLA}_{2} \mathrm{R}$ and THSD7A in patients' urine and sera were reviewed to provide newer and alternative techniques. We proposed the use of biomarkers ( $\mathrm{PLA}_{2} \mathrm{R}$ and THSD7A) in the diagnosis, treatment decision, and follow-up of patients with primary MGN. In addition, other prognostic renal biomarkers like retinol binding protein (RBP) and beta- 2 microglobulin were reviewed to detect the progression of renal damage for early intervention.
\end{abstract}

Keywords: M-type phospholipase A2; thrombospondin type containing domain A7; retinol binding protein; beta-2 microglobulin; membranous glomerulonephritis; neutral endopeptidase

\section{Introduction}

Membranous glomerulonephritis (MGN) is characterized by the deposit of the immune complex at the subepithelial region of the glomerular membrane and the formation of perpendicular projection similar to the glomerular basement membrane (GBM) found between podocyte cytoplasm and GBM [1]. The histological characteristics of MGN include GBM thickening, staining of the C3 complement along the periphery of glomerular capillaries, granular staining for immunoglobulin $\mathrm{G}$ subtype, and deposition of the immune complex at the subepithelium found exclusively in primary MGN [2].

Studies have shown that MGN is the most common cause of nephrotic syndrome among adults, consisting of up to $20 \%$ of cases among Hispanic and African Americans. Whites are the most affected, followed by Asians, Africans, and Hispanics [3,4]. MGN accounts for 1.5-9\% of the nephrotic syndrome among children and $21-35 \%$ in adults. The disease is predominantly seen among adults aged 40-50 years, with a male to female ratio of (2:1)-(3:1) [5]. 
Idiopathic or primary MGN is the commonest type seen in about $75 \%$ of the patients with MGN while the remaining $25 \%$ manifest as a secondary disease to other conditions, mainly infection [6-9].

It is very difficult to differentiate between primary and secondary MGN based on their clinical presentations and laboratory evaluations. Therefore, good leading history, clinical, and laboratory findings (including renal biopsy) are crucial in differentiating the two types of MGN [10]. Diagnosis of MGN is traditionally made through electron microscopy, light microscopy, and immunofluorescence techniques from renal biopsy [11].

There are a lot of attempts to use less invasive methods, like serum samples, or non-invasive methods, like urine samples, to make a diagnosis and monitor MGN patients immediately following the detection of anti-phospholipase $\mathrm{A} 2$ receptor $\left(\mathrm{PLA}_{2} \mathrm{R}\right)$ and anti-thrombospondin domain containing 7A (THSD7A) in the serum of primary MGN patients. Despite these tremendous achievements, making a diagnosis using serum alone is still difficult due to the lack of a cut-off point value universally agreed on for diagnosis and follow-up. Moreover, certain forms of secondary diseases are associated with these biomarkers.

Hence, this review aims at highlighting the newer techniques used in making a diagnosis of MGN by detecting biomarkers in serum and urine samples of MGN and the importance of those biomarkers in patient management.

\section{Pathogenesis}

Immune complex formation in the subepithelial surface of the glomerular complex membrane is central to the formation of membranous glomerulonephritis [12]. Three major mechanisms have been proposed so far [1,2].

The first hypothesis emphasizes on passive entrapment of preformed immune complex due to higher intraglomerular pressure and negatively charged capillary which force the protein across the glomerular capillary wall. An example is in lupus nephritis [13,14].

The second hypothesis involves the localization of the circulating antigens in the subepithelial aspect of the glomerular basement membrane, as such, the antigen forms in-situ immune complex deposit with the antibodies. This is seen in hepatitis B [15,16], hepatitis C [17,18], Helicobacter pylori [19], and patients diagnosed with MGN [20,21].

The third mechanism focuses on the binding of autoantibodies to antigens, as well as to podocyte membrane, leading to immune complex deposition. Numerous studies were conducted to describe the pathogenesis of MGN, ranging from the Heymann rat model of 1959 where membranous glomerulonephritis was induced using Lewis rats with crude kidney extract [22]. The use of megalin in the 1980s by Kerjaschki and Farquhar showed oxygen radicals responsible for glomerular damage resulting in proteinuria [23]. No anti-megalin antibody was recorded to have been found in patients with MGN. Therefore, megalin cannot be associated with proteinuria in human [12,24].

\section{Materials and Methods}

Pubmed, Google Scholar, Springer, and Science Direct were searched for manuscripts published in English using keywords, such as "primary OR idiopathic membranous nephropathy" alone or in combination with "prognosis" or "clinical features". Review articles were cited to provide more details and additional references.

\subsection{The Biomarkers}

Neutral endopeptidase (NEP) is the first human biomarker for MGN identified in early 2000s and is seen in patients with alloimmune neonatal MGN. This involves vertical transmission from a mother to her offspring following sensitization during previous pregnancy [25]. Therefore, it is very important to screen families with a history of membranous nephropathy as part of their antenatal care [25,26].

Beck et al. (2009) conducted a breakthrough study where a M-type phospholipase A2 receptor $\left(\mathrm{PLA}_{2} \mathrm{R}\right)$ was detected as a biomarker for MGN using Western blot technique. More recently, another 
biomarker, thrombospondin domain containing 7A (THSD7A) was discovered to complement PLA 2 R. This biomarker is detected in seronegative anti-PLA ${ }_{2} \mathrm{R}$ primary MGN patients except for some rare conditions where anti-PLA 2 R and anti-THSD7A can be detected $[27,28]$. Anti-THSD7A cannot be detected in a normal individual or patients with secondary MGN [29,30].

Anti-THSD7A occur in 2.5-5\% of patients with idiopathic MGN and does not appear in secondary MGN. Except for few where both PLA 2 R and THSD7A were found positive, THSD7A is only detected among those MGN patients who are $\mathrm{PLA}_{2} \mathrm{R}$ negative [31,32].

\subsubsection{Clinical Feature}

Nephrotic range proteinuria is the commonest presentation among MGN patients. It occurs in $70-80 \%$ of patients associated with edema, hypoalbuminemia, and hyperlipidemia, while the remaining patients present with subnephrotic range proteinuria [3,4,33-36]. The renal function may be normal or slightly impaired at diagnosis. An abrupt change in renal functions may call for a prompt investigation to look for possible superimposed conditions like bilateral renal thrombosis, drug toxicity, and crescentic glomerulonephritis [37]. Other features include hematuria; hypertension is mostly not specific to idiopathic membranous nephropathy [38].

A study involved the administration of THSD7A-specific IgG to mice, thereby leading to massive proteinuria and histomorphological changes of MGN. The above findings showed that anti-THSD7A antibodies might interfere with the integrity of podocyte resulting in damage of cells and subsequently proteinuria [39].

Most of the patients presenting with subnephrotic proteinuria are asymptomatic and have a natural history different from those with nephrotic range proteinuria. About $40 \%$ will have spontaneous remission, needing just conservative management while the remaining $60 \%$ may develop nephrotic range proteinuria within 2 years of presentation, especially when the anti-PLA $2 \mathrm{R}$ antibody is still present $[40,41]$. The progression of the disease is four times accelerated, which becomes synonymous to those that presented with nephrotic syndrome ab initio [42]. This is another scenario in which anti-PLA 2 R measurement may be important [5].

\subsection{2. $\mathrm{PLA}_{2} \mathrm{R}$-Related Sarcoidosis and Hepatitis B Virus (HBV) Infection}

Sarcoidosis is rarely seen in glomerular diseases. However, when it occurs, it is frequently associated with MGN $[43,44]$. The pathogenesis linking MGN to sarcoidosis remains unclear due to the inability to identify a target antigen or specific antibody linking the two diseases. Notably, while MGN resulted from an autoimmune reaction involving type-2 helper (Th2) cells, sarcoidosis is associated with type-1 helper (Th1) cells [45,46]. Stehle et al. (2015) demonstrated a high prevalence of anti-PLA ${ }_{2} \mathrm{R}$ antibodies in the serum of MGN patients with sarcoidosis [44].

In addition to sarcoidosis, $\mathrm{PLA}_{2} \mathrm{R}$ was detected in $64 \%$ hepatitis $\mathrm{B}$ virus (HBV) related MGN [47]. This may be due to co-localization of $\mathrm{PLA}_{2} \mathrm{R}$ and $\mathrm{HB}_{\mathrm{s}} \mathrm{Ag}$ in $\mathrm{HBV}$-related MGN due to chronic HBV infection $[48,49]$.

\subsubsection{THSD7A and Malignancy}

Patients with anti-THSD7A were found to be at risk of reoccurrence after transplant [50]. It has been observed that the messenger RNA for THSD7A was detected in gall bladder carcinoma and not in the normal gall bladder [51]. Serum samples of 1276 patients with MGN were screened for anti-THSD7A. Forty of them tested positive for anti-THSD7A and 8 out of the 40 developed malignancy within an average follow-up period of 3 months. Thus, this finding denoted that THSD7A is associated with malignancy [52]. In another study involving 81 patients with breast cancer and 20 with colorectal cancer, THS7A expression was detected by immunohistochemical stains in 100\% and $97.5 \%$ of breast cancer and colorectal cancer, respectively [53]. 


\subsubsection{Role of Biomarkers in Kidney Transplant}

The discovery of $\mathrm{PLA}_{2} \mathrm{R}$ does not only help in differentiating primary and secondary MGN but also helps in pre- and post-kidney transplantation by identifying those at risk of post-transplantation failure for intensive therapy and monitoring [54-56]. About 30-50\% of primary MGN patients are at risk of reoccurrence following kidney transplant especially among those with very high anti-PLA $\mathrm{A}_{2} \mathrm{R}$ antibodies titer $[57,58]$. Anti-PLA $2 \mathrm{R}$ titer should be considered post-transplantation, even though the threshold of anti-PLA ${ }_{2} \mathrm{R}$ level determining the reoccurrence is not clear [59] (Figure 1).

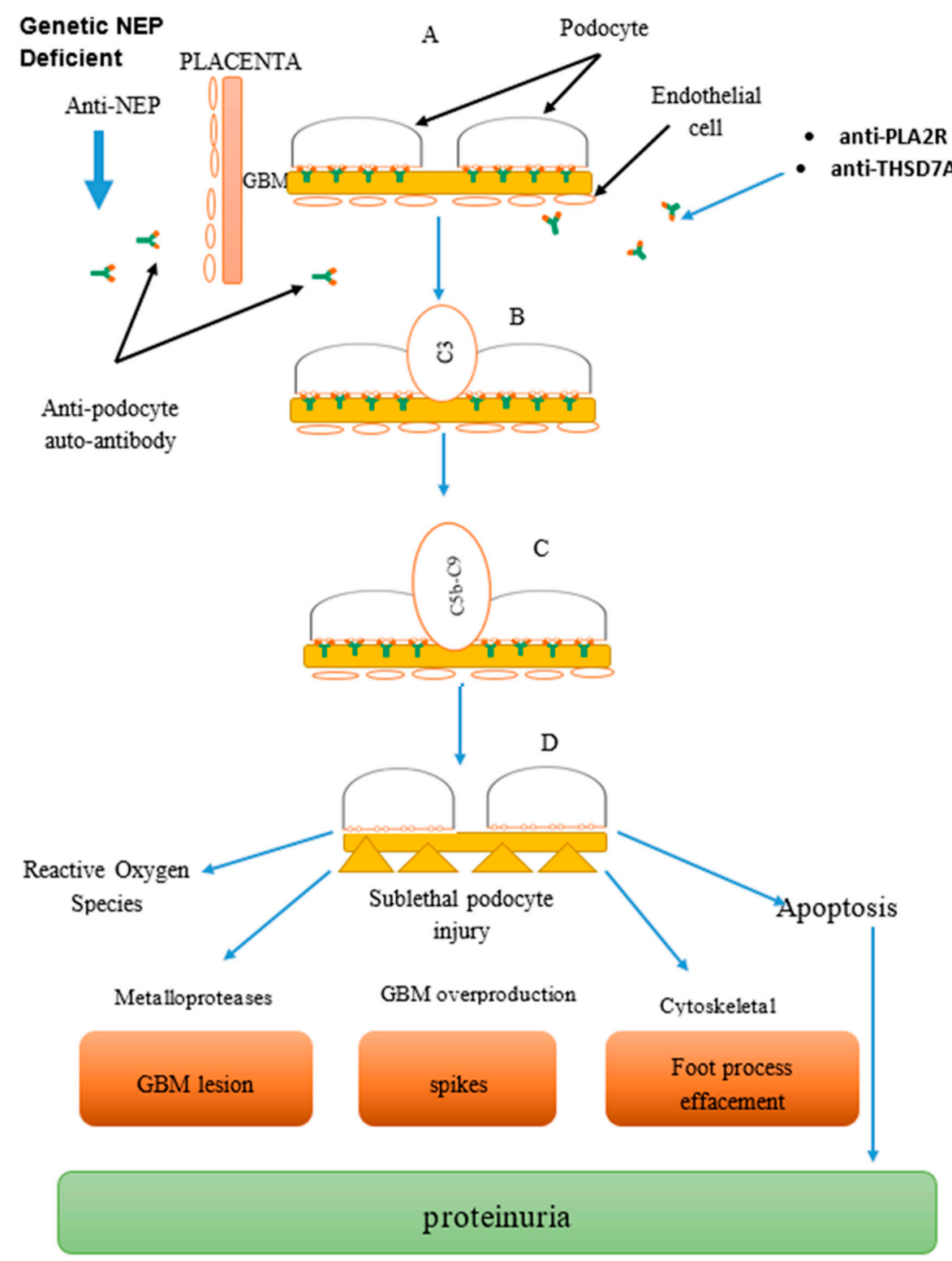

Figure 1. Combined image: Mechanism of anti-podocyte (anti-neutral endopeptidase (NEP), anti-phospholipase $\mathrm{A} 2$ receptor $\left(\mathrm{PLA}_{2} \mathrm{R}\right)$, anti-thrombospondin domain containing 7A (THSD7A)) antibody-mediated disease in membranous glomerulonephritis (MGN), part of glomerular basement membrane (GBM). Formation of complexes: (A) Antigen-antibody reacts to form complexes at the podocyte. (B) Complement activation system via the classical and alternative pathway. (C) Formation of complement membrane attack complex leading to cell injury. (D) Podocyte injury leading to proteinuria and cell death. 


\subsection{Detection of Biomarkers}

The following methods can be used in detecting PLA $2 \mathrm{R}$ and THSD7A antibodies in the patients' sera: Enzyme-Linked Immunosorbent Assay (ELISA) method, Laser Bead Immunoassay (ALBIA), Luciferase Immunoprecipitation System (LIPS) [60]. Recently, different methods of detecting anti-PLA ${ }_{2} \mathrm{R}$ and THSD7A are available commercially due to the rise in their clinical applications in patient management.

\subsubsection{Western Blot Technique}

Western blot technique is the first method used to detect the expression of anti-PLA $2 \mathrm{R}$ in the patient's serum with primary MGN [61]. In the Western blot technique, proteins are separated based on their molecular weight through gel electrophoresis [62]. The technique was first reported to have a sensitivity of about $70 \%$ with up to $96 \%$ specificity [61]. There were also reports on an improved variant of the Western blot technique (specially designed to detect very low anti-PLA ${ }_{2} \mathrm{R}$ ) with sensitivity even greater than $90 \%$ [63]. However, the method is only suitable for a smaller sample size and also requires expertise [64].

\subsubsection{Recombinant Cell-Indirect Immunoassay (RC-IFA)}

In this case, the substrate is human cell-line HEK293-overexpressing the full-length $\mathrm{PLA}_{2} \mathrm{R}_{1}$ [65]. RC-IFA can be used to make a diagnosis and monitor primary MGN patients. It was shown to have a sensitivity of $75 \%$ and a specificity of nearly $100 \%$ [66]. RC-IFA has been considered the most suitable method for the detection of anti-PLA 2 R1 [67]. It can also be used as a reference technique to determine several antibodies against the membrane proteins of the outer surface like NMDR in autoimmune encephalitis [68], aquaporin 4 in neuromyelitis optica [69], and Crohn's disease [70].

Despite all the advantages mentioned above, it has its limitations. RC-IFA requires technical know-how and special equipment like fluorescence microscopy. It is liable to subjective interpretation and it can only give a semi-quantitative variable.

\subsubsection{Time-Resolved Fluoroimmunoassay (TRFIA)}

This is a highly specific antigen-antibody binding reaction by measuring light-emission from labels conjugated from protein [71,72]. This assay has high sensitivity, used in the quantitative measurement of serum PLA 2 R-Ab immunoglobulin (IgG4) [73].

\subsubsection{Laser Bead Immunoassay (ALBIA)}

Behnert et al. (2013) reported the use of Laser Bead Immunoassay (ALBIA) using an in vivo expressed recombinant human $\mathrm{PLA}_{2} \mathrm{R}$ to take care of limitations of RC-IFA (quantitative assay, high objectivity in assessment) [74]. Further study was carried out to compare with two other commercially available immunoassays. It was proved that ALBIA correlates better with RC-IFA than with ELISA $(p=0.003)$ and the overall result showed sensitivity and specificity of $60 \% / 98.6 \%$, and $56.2 \% / 100 \%$ for ALBIA and RC-IFA, respectively [75]. Despite this remarkable result for ALBIA, it is not available commercially.

\subsubsection{Luciferase Immunoprecipitation System (LIPS)}

Another technique is the LIPS assay that makes use of light-emitting proteins. This can detect different types of antibodies, including anti-PLA 2 R [76]. The PLA 2 R LIPS assay is quantitative and highly sensitive. It has a sensitivity of nearly $100 \%$ and a specificity of $100 \%$ and is better than most of these methods of detecting $\mathrm{PLA}_{2} \mathrm{R}$. It can also positively correlate with proteinuria and disease process $(p<0.005)$ [60]. More studies are needed to prove the above claim, and its uses are limited to research only (not yet available commercially). 


\subsubsection{Enzyme-Linked Immunosorbent Assay (ELISA)}

There is an urgent need to develop a standardized ELISA to overcome the above-mentioned shortcomings and to give identical diagnostic accuracy for better clinical importance. This involves the expression of PLA 2 R1 in HEK293. This technique was used to analyze sera from 200 primary MGN patients, 27 secondary MGN, and 291 healthy individuals. The results indicated a remarkable sensitivity of $78 \%$ and a specificity of $91 \%$. The result has correlated significantly well with clinical findings of patients and the results obtained from RC-IFA [64].

A comparative study involving different methods of detecting $\mathrm{PLA}_{2} \mathrm{R}$ antibody among 158 patients was conducted of which 142 were primary and 16 were secondary MGN. Western blot, ELISA, and IIFT techniques were compared, and the results showed a specificity of $97 \%$ for all techniques, a sensitivity of $68 \%$ for IIFT, and $72 \%$ for both ELISA and the Western blot technique. The ELISA technique may be the preferred method because it can be used for a larger sample size, both qualitative and quantitative measurements. It is less time consuming, requires less technical know-how, and can be interpreted objectively. This clearly showed the superiority of the ELISA method in terms of commercial availability and clinical application [77].

Western blot, ELISA, and RC-IFA are widely used due to their commercial availability and technically. The ELISA technique is widely used compared to other methods due to its ability to measure both qualitative and quantitative assays, and also for its affordability. Table 1 below shows the superiority of the ELISA technique over other methods.

Table 1. Showing various techniques used in detecting $\mathrm{PLA}_{2} \mathrm{R}$ antibody.

\begin{tabular}{ccccc}
\hline Techniques & No. of Subjects & Sensitivity (\%) & Specificity (\%) & References \\
\hline Western blot & 37 & 70 & 96 & {$[61]$} \\
ALBIA & 157 & 60 & 96 & {$[75]$} \\
LIPS & 45 & 97 & 100 & {$[60]$} \\
ELISA & 200 & 96.5 & 99.99 & {$[64]$} \\
TRFIA & 39 & 89.7 & 100 & {$[73]$} \\
RC-IFA & 75 & 75 & 100 & {$[66]$} \\
\hline
\end{tabular}

\subsubsection{Detection of Anti-PLA 2 R and Anti-THSD7A in Serum}

A meta-analysis involving 19 studies and 1160 patients was conducted to investigate the clinical importance and the accuracy of histological and serological $\mathrm{PLA}_{2} \mathrm{R}$ in differentiating primary and secondary MGN. The overall results showed a sensitivity of 0.68 , specificity of 0.97 , and the diagnostic odds ratio (DOR) was 3.75, while the area under the receiver operating curve (AUROC) was 0.82 for serum anti-PLA $\mathrm{A}_{2} \mathrm{R}$ with a substantial heterogenicity $\left(\mathrm{I}^{2}=86.42 \%\right)$. In the case of $\mathrm{PLA}_{2} \mathrm{R}$ staining, the overall sensitivity was 0.78 , specificity was 0.91 , and DOR (34.70) and AUROC (0.84) without heterogenicity $\left(\mathrm{I}^{2}=0 \%\right)$. Thus, serum anti-PLA $\mathrm{A}_{2} \mathrm{R}$ can be used to make a diagnosis of primary MGN, but in the case of serum anti-PLA $2 \mathrm{R}$ negative patients, clinical presentation and biopsy must be considered before making the diagnosis $[78,79]$.

Another study involved 57 biopsy-proven primary MGN, 62 non-MGN, and 22 healthy individuals using the ELISA technique to quantify anti-PLA $2 \mathrm{R}$ in the serum. The results obtained show that at a cut-off value of $2.0 \mathrm{RU} / \mathrm{mL}$, the sensitivity and specificity were $75 \%$ and $82.5 \%$, respectively. At $2.6 \mathrm{RU} / \mathrm{mL}$, the sensitivity and specificity were $78.9 \%$ and $91.7 \%$, respectively, while the sensitivity and specificity at $20 \mathrm{RU} / \mathrm{mL}$ were found to be $50.9 \%$ and $96.4 \%$, respectively. As the cut-off value increases, the sensitivity and specificity also increase [80].

THSD7A is a form of membrane-associated $N$-glycoprotein found within endothelial cells of the human umbilical vein and also expressed in blood vesicles of the placenta [81].

A study conducted in 154 primary MGN patients demonstrated that 15 of the 154 patients have antibodies for only anti-THSD7A [58]. Subsequently, more researches were conducted to detect the level of anti-THSD7A in the serum of MGN patients. Anti-THSD7A can be detected in serum and tissue 
of primary MGN patients with THSD7A [82]. Unlike PLA 2 R, THSD7A does not show any significant preference for serum creatinine, albumin, and proteinuria levels [83]. No significant correlation was found between THSD7A and proteinuria [52].

In a meta-analysis of 10 different studies involving 4121 patients with primary MGN and based on sample size, race, and detection method, it was found that anti-THSD7A was 3\% in all patients and $10 \%$ among those without anti-PLA ${ }_{2} \mathrm{R}$. Thus, this clearly showed a significant difference in the prevalence of anti-THSD7A based on the sample size but not many differences were observed among the races [39].

In a study conducted on 1318 biopsy-proven primary MGN, 31 stained positives for THS7A showed a strong correlation with IIFT results $(p<0.001)$ [82].

\subsubsection{Detection of Anti-PLA ${ }_{2} \mathrm{R}$ and Anti-THSD7A in Urine}

A urine sample is non-invasive and can detect renal damage more than serum. Therefore, it is important to demonstrate whether anti-PLA $\mathrm{P}_{2} \mathrm{R}$ can be detected in urine. To do this, a study was conducted on 28 primary MGN and 12 secondary MGN patients in China using ELISA and IIFT. The result showed that 18 of the $28(64.3 \%)$ primary MGN patients tested positive for IIFT serum PLA ${ }_{2} R$, while 19 of the $28(67.9 \%)$ had IIFT positive urinary anti-PLA ${ }_{2} \mathrm{R}$. The antibody titer of anti-PLA ${ }_{2} \mathrm{R}$ from primary MGN patients in urine and serum is higher than the corresponding titers from secondary MGN $(p<0.05)$. Statistical analysis indicated a positive correlation between urinary anti-PLA ${ }_{2} R$ and serum anti-PLA $A_{2} R$. More studies needed to prove that anti-PLA $A_{2} R$ can be detected in the urine of primary MGN patients [84].

Despite several studies involved in the detection of THSD7A in tissue and serum, no known published study is regarding its detection in the patients' urine.

\subsection{Diagnosis}

Previous studies showed that anti-PLA ${ }_{2} \mathrm{R}$ is now an established parameter for diagnosing primary MGN, differentiating it from secondary type, monitoring treatment, and prognosis [85]. The antibody titer helps in monitoring treatment more than proteinuria as the change in titer is immunological, so it precedes the change in proteinuria [11].

All patients with biopsy-proven MGN should be screened for anti-PLA ${ }_{2} \mathrm{R} / \mathrm{THSD7A}$, as well as hepatitis $C$, hepatitis $B$, lupus nephritis antigens, and malignancies to rule out secondary causes [86-88].

Most ELISA authors define positivity of anti-PLA $\mathrm{A}_{2} \mathrm{R}$ using a cut-off point of $20 \mathrm{RU} / \mathrm{mL}$, some use $14 \mathrm{RU} / \mathrm{mL}, 2.6 \mathrm{RU} / \mathrm{mL}$, or $2 \mathrm{RU} / \mathrm{mL}$ as their cut-off point value to define positivity [89-92]. In some cases, the cut-off point value is obtained by measuring the anti-PLA ${ }_{2} \mathrm{R}$ of apparently normal subjects without any renal compromised [93].

Though detection of anti-PLA $\mathrm{R}_{2} \mathrm{R}$ and anti-THSD7A in serum were found to be reliable, biopsy remains the best option in the diagnosis of primary MGN. A study conducted on 42 biopsies has proven primary MGN with serum samples collected at the time of biopsy. The resultant sensitivities and specificities were 0.74 and 0.57 for renal glomerular deposit and circulating anti-PLA $\mathrm{R}_{2}$ in serum, respectively, with 3 patients who had no $P L A_{2} R$ but detectable anti-PLA ${ }_{2} R$ in their serum. Furthermore, 18 patients who were serum anti-PLA $A_{2} R$ negative have a glomerular deposit of $P_{L A} R$. This study suggested that both biopsy and serum are very important in making the diagnosis of primary MGN [94].

\subsection{Treatment of Idiopathic MGN and Further Therapy}

Serum and urine biomarkers ( $\mathrm{PLA}_{2} \mathrm{R}$ and THSD7A) are now used in monitoring the efficiency of immunosuppressive therapy. The biomarkers can also be used to compare two immunosuppressive drugs by measuring the serum level of $\mathrm{PLA}_{2} \mathrm{R}$ and THSD7A before, during, and after treatment [95-98]. Rituximab can be used to reduce PLA $\mathrm{A}_{2} \mathrm{R}$. However, the total dose needed to clear anti-PLA $\mathrm{A}_{2} \mathrm{R}$ remains unclear and may be patient dependent [99]. 
Another suggestion was the use of drugs that inhibit the factors that activate autoreactive $B$ cells. In this case, Belimumab acts by reducing the production of autoantibodies by binding to a B-lymphocyte Stimulator (BLyS) [100]. In a study involving 14 patients, it was found that Belimumab caused significant reduction in anti-PLA ${ }_{2} \mathrm{R}$ and proteinuria and normalized the serum albumin level [101].

\subsection{Prognosis}

Recent studies conducted within 5 years have shown that anti-PLA ${ }_{2} \mathrm{R}$ concentration is correlated with urinary protein and disease activities; the antibodies are usually undetectable in spontaneous or drug-induced remission patients and reappear when there is relapse [102-106].

Toronto risk score has been used to predict the prognosis of MGN patients. It is calculated based on creatinine clearance at diagnosis, highest sustained 6 months period of proteinuria, and slope of creatinine clearance over 6 months with an accuracy level of up to $90 \%$. However, there are challenges associated with this method which include complex calculation and prolonged observation of up to 18 months which may delay treatment [107]. Recently, biomarkers like $P_{L A} R$, retinol binding protein (RBP), and beta-2 microglobulin can be used to predict prognosis among patients with MGN [108].

RBP is considered to be a prognostic biomarker for MGN and other chronic kidney diseases. The high value of RBP is associated with poor prognosis $[109,110]$.

$\beta 2$-microglobulin can predict the prognosis of MGN [111,112]. $\beta 2$-microglobulin has $88 \%$ sensitivity and $91 \%$ specificity in determining the prognosis in renal failure with the threshold level at $40 \mathrm{mg} / \mathrm{min}$ [111]. However, when re-evaluated, both biomarkers show low sensitivity and specificity compared to the initial result. This may be due to conservative therapy. There are no significant differences between prognostic accuracies from $\beta 2$-microglobulin and Toronto risk score [107].

A retrospective study involving 33 non-nephrotic MGN patients showed that anti-PLA ${ }_{2} R$ positive patients $(48 \%)$ were more at risk of progressing towards a nephrotic syndrome compared to anti-PLA $\mathrm{A}_{2} \mathrm{R}$ negative patients. In addition, patients with high anti-PLA ${ }_{2} \mathrm{R}$ titer are more at risk of adverse effects of immunosuppressive drugs and end-stage renal disease compared to those with no anti-PLA ${ }_{2} \mathrm{R}$ by the end of the follow-up [105]. More studies involving a large number of patients are needed to confirm the above claim, as the small number of patients in this study and the too short follow-up duration rendered it hard to categorically determine the outcome.

To accurately predict the progression of MGN, the watchful waiting method was adopted. This involves $24 \mathrm{~h}$ urinary protein and creatinine clearance monitoring for at least 6 months and comparing the result with nephrotic range proteinuria [108].

It is important to know that the presenting proteinuria is inversely proportional to the rate of spontaneous remission [112]. Further, it was observed that there is a high chance of spontaneous remission if a $50 \%$ reduction in proteinuria is achieved within the first year irrespective of the initial level of proteinuria. About $32 \%$ can undergo spontaneous remission within 14 months and up to $62 \%$ in 5 years especially among MGN patients with decreased (low) anti-PLA ${ }_{2} R$ and anti-THSD7A $[29,41,113]$.

More recent studies support a watchful waiting approach and also indicated that spontaneous remission can occur even when the presenting proteinuria is greater than $12 \mathrm{~g} /$ day [113].

Further studies involving natural history and spontaneous remission in Southeast Asia and Malaysia are needed.

\section{Conclusions}

The standardized ELISA method is the best so far considering its ability to measure both qualitative and quantitative variables, it requires less time, it is easier to perform, it has high sensitivity and specificity, and is also readily available and affordable commercially.

Serum or urine samples should be used to determine the level of anti-PLA ${ }_{2} \mathrm{R} /$ anti-THSD7A to make a diagnosis, monitor patients' treatment, and to determine the prognosis especially among patients 
who cannot withstand renal biopsy. Serum and urine samples can determine when to commence or stop immunosuppressive therapy.

Funding: The review was sponsored by Universiti Putra Malaysia (UPM) grant.

Conflicts of Interest: The authors declare no conflict of interest. The funders had no role in the design of the study; in the collection, analyses, or interpretation of data; in the writing of the manuscript, or in the decision to publish the results.

\section{References}

1. Larsen, C.P.; Messias, N.C.; Silva, F.G.; Messias, E.; Walker, P.D. Determination of primary versus secondary membranous glomerulopathy utilizing phospholipase A2 receptor staining in renal biopsies. Modern Pathol. 2012, 26, 709-715. [CrossRef]

2. Fogo, A.B.; Lusco, M.A.; Najafian, B. AJKD atlas of renal pathology: Membranous nephropathy. Nephrol. Dial. Transplant. 2011, 26, 3425-3426. [CrossRef]

3. Salant, D.J. Membranous nephropathy. Port. J. Nephrol. Hypert. 2015, 33, 239-251.

4. Cattran, D.C.; Brenchley, P.E. Membranous nephropathy: Integrating basic science into improved clinical management. Kidney Int. 2017, 566-574. [CrossRef]

5. Cattran, D.; Brenchley, P. Membranous nephropathy: Thinking through the therapeutic options. Nephrol. Dial. Transpl. 2017, 32, i22-i29. [CrossRef]

6. Seitz-Polski, B.; Dolla, G.; Payre, C.; Girard, C.A.; Polidori, J.; Zorzi, K.; Birgy-Barelli, E.; Jullien, P.; Courivaud, C.; Krummel, T.; et al. Epitope Spreading of Autoantibody Response to PLA2R Associates with Poor Prognosis in Membranous Nephropathy. J. Am. Soc. Nephrol. 2016, 27, 1517-1533. [CrossRef]

7. Feng, Z.; Wang, S.; Huang, Y.; Liang, X.; Shi, W.; Zhang, B. A follow-up analysis of positron emission tomography/computed tomography in detecting hidden malignancies at the time of diagnosis of membranous nephropathy. Oncotarget 2016, 7, 9645. [CrossRef]

8. Zeng, C.H.; Chen, H.M.; Wang, R.S.; Chen, Y.; Zhang, S.H.; Liu, L.; Li, L.S.; Liu, Z.H. Etiology and Clinical Characteristics of Membranous Nephropathy in Chinese Patients. Am. J. Kidney Dis. 2008, 52, 691-698. [CrossRef]

9. Lefaucheur, C.; Stengel, B.; Nochy, D.; Martel, P.; Hill, G.S.; Jacquot, C.; Rossert, J. Membranous nephropathy and cancer: Epidemiologic evidence and determinants of high-risk cancer association. Kidney Int. 2006, 70, 1510-1517. [CrossRef]

10. KDIGO Clinical Practice Guideline for Glomerulonephritis. Available online: https://www.theisn.org/ education-home/gop-articles/item/594-kdigogn (accessed on 28 March 2014).

11. Mastroianni-Kirsztajn, G.; Hornig, N.; Schlumberger, W. Autoantibodies in renal diseases-clinical significance and recent developments in serological detection. Front. Immunol. 2015, 6, 1-6. [CrossRef]

12. Ling, W.; Hao, T.; Chen, P.M.; Chan, C.K.; Chiang, W.C.; Chen, Y.M.; Wu, K.D. Science Direct Membranous nephropathy: A review on the pathogenesis, diagnosis, and treatment. J. Formos. Med. Assoc. 2015, 114, 102-111.

13. Shlomchik, M.J.; Madaio, M.P. The role of antibodies and B cells in the pathogenesis of lupus nephritis. Springer Semin. Immunopathol. 2003, 24, 363-375. [CrossRef] [PubMed]

14. Wilcox, T.; Hirshkowitz, A. The role of B cells in Lupus pathogenesis. Int. J. Biochem. Cell Biol. 2010, 42, 543-550.

15. Bhimma, R.; Coovadia, H.M. Hepatitis B virus-associated nephropathy. Am. J. Nephrol. 2004, 24, 198-211. [CrossRef]

16. Moon, J.Y.; Lee, S.H. Treatment of Hepatitis B Virus-Associated Membranous Nephropathy: Lamivudine Era versus Post-Lamivudine Era. Korean J. Intern. Med. 2012, 27, 394-396. [CrossRef]

17. Sandri, A.M.; Elewa, U.; Poterucha, J.J.; Fervenza, F.C. Treatment of hepatitis C-mediated glomerular disease. Nephron. Clin. Pract. 2011, 119, 121-130. [CrossRef]

18. Morales, J.M.; Kamar, N.; Rostaing, L. Hepatitis $C$ and renal disease: Epidemiology, diagnosis, pathogenesis. Hepat. C Ren. Dis. Hemodial. Transplant. 2012, 176, 10-23. 
19. Dede, F.; Ayli, D.; Gonul, I.; Yuksel, O.; Ozturk, R.; Yildiz, A.; Yenigun, E.; Piskinpasa, S.; Turgut, D.; Koc, E.; et al. The effect of Helicobacter pylori eradication on proteinuria in patients with primary glomerulonephritis. Arch. Med. Sci. 2015, 11, 764-769. [CrossRef]

20. Lien, Y.H. Pathogenesis, diagnosis and management of paraneoplastic glomerulonephritis. Nat. Rev. Nephrol. 2011, 7, 85-95. [CrossRef]

21. Beck, L.H.; Salant, D.J. Membranous nephropathy: Recent travels and new roads ahead. Kidney Int. 2010, 77, 765-770. [CrossRef]

22. Heymann, W.; Hackel, D.B.; Harwood, S.; Wilson, S.G. Production of nephrotic syndrome in rats by Freund's adjuvants and rat kidney suspensions. Proc. Soc. Exp. Biol. Med. 1959, 100, 660-664. [CrossRef] [PubMed]

23. Farquhar, M.G.; Saito, A.; Kerjaschki, D. The Heymann nephritis antigenic complex: Megalin (gp330) and RAP. J. Am. Soc. Nephrol. 1995, 6, 35-47. [CrossRef] [PubMed]

24. Ronco, P.; Debiec, H. Pathophysiological advances in membranous nephropathy: Time for a shift in patient's care. Lancet 2015, 385, 1983-1992. [CrossRef]

25. Hu, P.; Xuan, Q.; Hu, B.; Lu, L.; Qin, Y.H. Anti-neutral endopeptidase natriuretic peptides, disarrangement and proteinuria onset in membranous nephropathy. Mol. Biol. Rep. 2013, 40, 2963-2967. [CrossRef]

26. Debiec, H.; Nauta, J.; Coulet, F.; van der, B.M.; Guigonis, V.; Schurmans, T. Role of truncating mutations in MME gene in fetomaternal alloimmunisation and antenatal glomerulopathies. Lancet 2004, 364, 1252-1259. [CrossRef]

27. Larsen, C.P.; Cossey, L.N.; Beck, L.H. THSD7A staining of membranous glomerulopathy in clinical practice reveals cases with dual autoantibody positivity. Mod. Pathol. 2016, 29, 421-426. [CrossRef]

28. Gödel, M.; Grahammer, F.; Huber, T.B. Thrombospondin Type-1 Domain-Containing 7A in Idiopathic Membranous Nephropathy. N. Engl. J. Med. 2015, 372, 1073-1075.

29. Hofstra, J.M.; Beck, L.H.; Beck, D.M.; Wetzels, J.F.; Salant, D.J. Anti-phospholipase a2 receptor antibodies correlatewith clinical status in idiopathic membranous nephropathy. Clin. J. Am. Soc. Nephrol. 2011, 6, 1286-1291. [CrossRef]

30. Prunotto, M.; Carnevali, M.L.; Candiano, G.; Murtas, C.; Bruschi, M.; Corradini, E.; Trivelli, A.; Magnasco, A.; Petretto, A.; Santucci, L.; et al. Autoimmunity in membranous nephropathy targets aldose reductase and SOD2. J. Am. Soc. Nephrol. 2010, 21, 507-519. [CrossRef]

31. Liu, L.Y.; Lin, M.; Lai, Z.; Jiang, J.; Huang, Y.; Jao, L. Motor neuron-derived Thsd7a is essential for zebrafish vascular development via the Notch-dll4 signaling pathway. J. Biomed. Sci. 2016, 23, 59. [CrossRef]

32. Novel Nephrological Markers: Anti-PLA2R, anti-THSD7A and Uromodulin. Available online: https://www.google.com.hk/url?sa=t\&rct=j\&q=\&esrc=s\&source=web\&cd=1\&ved=2ahUKEwj2gtM88XlAhUXA4gKHR_cAcAQFjAAegQIABAC\&url=https $\% 3 \mathrm{~A} \% 2 \mathrm{~F} \% 2 \mathrm{Fwww}$.euroimmun.com\% 2Ffileadmin\%2Feuroimmun\%2Fpdf\%2Fnews\%2Farticle\%2FHA_1254_L_UK_B18.pdf\&usg= AOvVaw32W_ClcC3eRyofbMQM4anO (accessed on June 2016).

33. Kemp, W.L.; Burns, D.K.; Brown, T.G. Pathology of the Kidney and Bladder. In Pathology: The Big Picture; McGraw-Hill Medical: New York, NY, USA, 2008.

34. Thompson, A.; Cattran, D.C.; Blank, M. Complete and partial remission as surrogate end points in membranous nephropathy. J. Am. Soc. Nephrol. 2015, 2930-2937. [CrossRef] [PubMed]

35. Barbour, S.; Reich, H. Short-term complication of membranous nephropathy. Contrib. Nephrol. 2013, $143-151$.

36. Ponticelli, C.; Passerini, P. A randomized pilot trial comparing methylprednisolone plus a cytotoxic agent versus synthetic adrenocorticotropic hormone in idiopathic membranous nephropathy. Am. J. Kidney 2006, 47, 233-240. [CrossRef] [PubMed]

37. Nachman, P.H.; Jennette, J.C. Primary glomerular disease. In Brenner and Rector's the Kidney, 9th ed.; Elsevier: London, UK, 2012; pp. 1100-1191.

38. 5 rd Report of the Malaysian Registry of Renal Biopsy. Available online: https://www.google.com.hk/url?sa=t\&rct=j\&q=\&esrc=s\&source=web\&cd=1\&ved= 2ahUKEwiqmMae68flAhVUw4sBHfHyCFwQFjAAegQIAxAC\&url=https\%3A\%2F\%2Fwww.msn. org.my\%2Fmsn\%2FDoc\%2FPublicDoc_PB\%2FPublication\%2Fmrrb_report2012\%2FFULL_5th_2012.pdf\& usg=AOvVaw0nKLz64bns7kA7epTCeYeO (accessed on June 2012).

39. Ren, S.; Wu, C.; Zhang, Y.; Wang, A.Y.; Li, G.; Wang, L.; Hong, D. An update on clinical significance of use of THSD7A in diagnosing idiopathic membranous nephropathy: A systematic review and meta-analysis of THSD7A in IMN. Ren. Fail. 2018, 40, 306-313. [CrossRef] [PubMed] 
40. Guerry, M.J.; Vanhille, P.; Ronco, P. Serum anti-PLA2R antibodies may be present before clinical manifestations of membranous nephropathy. Kidney Int. 2016, 89, 1399. [CrossRef]

41. Stanescu, H.C.; Arcos-Burgos, M.; Medlar, A.; Bockenhauer, D.; Kottgen, A.; Ragomirescu, L. Risk HLA-DQA1 and PLA2R1 alleles in idiopathic membranous nephropathy. N. Engl. J. Med. 2011, 364, 616-626. [CrossRef]

42. Hladunewich, M.A.; Troyanov, S.; Calafati, J. The natural history of the non-nephrotic membranous nephropathy patient. Clin. J. Am. Soc. Nephrol. 2009, 4, 1417-1422. [CrossRef]

43. Stehlé, T.; Joly, D.; Vanhille, P.; Boffa, J.J.; Rémy, P.; Mesnard, L.; Hoffmann, M.; Grimbert, P.; Choukroun, G.; Vrtovsnik, F.; et al. Clinicopathological study of glomerular diseases associated with sarcoidosis: A multicenter study. Orphanet. J. Rare. Dis. 2013, 8, 65. [CrossRef]

44. Stehlé, T.; Audard, V.; Ronco, P.; Debiec, H. Phospholipase A2 receptor and sarcoidosis-associated membranous nephropathy. Nephrol. Dial. Transplant. 2015, 30, 1047-1050. [CrossRef]

45. Iannuzzi, M.C.; Rybicki, B.A. Sarcoidosis. N. Engl. J. Med. 2007, 357, 2153-2165. [CrossRef]

46. Debiec, H.; Ronco, P. Immunopathogenesis of membranous nephropathy: An update. Semin. Immunopathol. 2014, 36, 381-397. [CrossRef] [PubMed]

47. Xie, Q.; Li, Y.; Xue, J.; Xiong, Z.; Wang, L.; Sun, Z.; Ren, Y.; Zhu, X.; Hao, C.M. Renal Phospholipase A2 Receptor in Hepatitis B Virus-Associated Membranous Nephropathy. Am. J. Nephrol. 2015, 41, 345-353. [CrossRef] [PubMed]

48. Sasaki, Y.; Nagai, Y.; Mikami, T.; Akasaka, Y.; Shibuya, K.; Urita, Y. Anti-phospholipase A2 receptor antibody positive hepatitis $B$ virus-associated membranous nephropathy remitted with entecavir after relapse with lamivudine. J. Nephropathol. 2018, 7, 93-97. [CrossRef]

49. Xu, X.; Zhu, X.; Yuan, S.; Jiang, W.; Xia, Y.; Liu, H.; Li, J.; Sun, L.; Peng, Y.; Liu, F. Role of M-Type phospholipase A2 receptor and its antibody in hepatitis B virus-Associated membranous nephropathy. J. Cent. South. Univ. Med. Sci. 2016, 41, 1064-1068.

50. Tomas, N.M. Autoantibodies against thrombospondin type 1 domain-containing 7A induce membranous nephropathy. J. Clin. Investig. 2016, 126, 2519-2532. [CrossRef]

51. Hoxha, E.; Wiech, T.; Stahl, P.R. A mechanism for cancer-associated membranous nephropathy. N. Engl. J. Med. 2016, 374, 1995-1996. [CrossRef]

52. Hoxha, E.; Beck, L.H.; Wiech, T. An indirect immunofluorescence method facilitates detection of thrombospondin type 1 domain-containing 7A-specific antibodies in membranous nephropathy. J. Am. Soc. Nephrol. 2016, 28, 520-531. [CrossRef]

53. Xian, L.; Dong, D.; Luo, J.; Zhuo, L.; Li, K.; Zhang, P.; Wang, W.; Xu, Y.; Xu, G.; Wang, L.; et al. Expression of THSD7A in neoplasm tissues and its relationship with proteinuria. BMC Nephrol. 2019, 20,1-6. [CrossRef]

54. Quintana, L.F.; Miguel, B.; Miguel, S.; Perez, N.S.; Lopez-Hoyos, M.; Patricia, V.; Emillio, R.; Odette, V.; Guadalupe, E.; Fritz, D.; et al. Antiphospholipase A2 antibody predict the risk of post transplantation recurrence of membranous nephropathy. Transplantation 2015, 99, 1709-1714. [CrossRef]

55. Gupta, G.; Fattah, H.; Ayalon, R.; Kidd, J.; Gehr, T.; Quintana, L.F. Pretransplant phospholipase A2 receptor autoantibody concentration is associated with clinically significant recurrence of membranous nephropathy post-kidney transplantation. Clin. Transpl. 2016, 30, 461-469. [CrossRef]

56. Leon, J.; Pérez-Sáez, M.J.; Batal, I.; Beck, L.H.; Rennke, H.G.; Canaud, G.; Legendre, C.; Pascual, J.; Riella, L.V. Membranous Nephropathy Post-Transplantation. Transplantation 2019, 103, 1.

57. Debiec, H.; Lefeu, F.; Kemper, M.J.; Niaudet, P.; Deschênes, G.; Remuzzi, G.; Ulinski, T.; Ronco, P. Early-childhood membranous nephropathy due to cationic bovine serum albumin. N. Engl. J. Med. 2011, 364, 2101-2110. [CrossRef] [PubMed]

58. Tomas, N.M.; Beck, L.H.; Meyer-Schwesinger, C.; Seitz-Polski, B.; Ma, H.; Zahner, G.; Dolla, G.; Hoxha, E.; Helmchen, U.; Dabert-Gay, A.-S.; et al. Thrombospondin Type-1 Domain-Containing 7A in Idiopathic Membranous Nephropathy. N. Engl. J. Med. 2014, 371, 2277-2287. [CrossRef]

59. Wai, H.; Lim, M.S.G.W. Recurrent and de novo glomerulonephritis after kidney transplantation. Core Concepts Ren. Transplant. 2019, 10, 211-231.

60. Peter, D.B.; Beck Jr, L.H.; Waldman, M. Detection and Monitoring PLA2R Autoantibodies by LIPS in Membranous Nephropathy. J. Immunol. Methods 2017, 20, 48-55.

61. Beck Jr, L.H.; Bonegio, R.G.; Lambeau, G.; Beck, D.M.; Powell, D.W.; Cummins, T.D.; Klein, J.B. M-type Phospholipase A2 receptor as target antigen in idiopathic membranous nephropathy. N. Engl. J. Med. 2009, 361, 11-21. [CrossRef] 
62. Mahmood, T.; Yang, P.C. Western blot: Technique, Theory and Trouble shooting. N. Am. J. Med. Sci. 2012, 4, 429-434.

63. Qin, W.; Beck Jr, L.H.; Zeng, C.; Chen, Z.; Li, S.; Zuo, K.; Salant, D.J. Anti-phospholipase A2 receptor antibody in membranous nephropathy. J. Am. Soc. Nephrol. 2011, 22, 1137-1143. [CrossRef]

64. Dahnrich, C.; Komowski, L.; Probst, C.; Seitz-Polski, B.; Esnault, V.; Wetzels, J.F.; Hofstra, J.M.; Hoxha, E.; Stahl, R.A.; Lambeau, G.; et al. Development of standarzed ELISA for the determination of autoantibodies against human M-type phospholipase A2 receptor in primary membranous nephropathy. Clin. Chim. Acta 2013, 421, 213-218. [CrossRef]

65. Hoxha, E.; Blöcker, I.M.; Probst, C. Detection of PLA2R specific autoantibodies in patients with idiopathic membranous nephropathy using PLA2R producing HEK293 cells. In Proceedings of the 7th Congress on Autoimmunity, Ljubljana, Slovenia, 5-9 May 2010.

66. Hofstra, J.M.; Debiec, H.; Short, C.D. Antiphospholipase A2 receptor antibody titer and subclass in idiopathic membranous nephropathy. J. Am. Soc. Nephrol. 2012, 23, 1735-1743. [CrossRef]

67. Debiec, H. Nephrotic syndrome: A new specific test for idiopathic mem- branous nephropathy. Nat. Rev. Nephrol. 2011, 7, 496-498. [CrossRef] [PubMed]

68. Wandinger, K.P.; Saschenbrecker, S.; Stoecker, W. Anti-NMDA-receptor en- cephalitis: A severe, multistage, treatable disorder presenting with psychosis. J. Neuroimmunol. 2011, 231, 86-91. [CrossRef] [PubMed]

69. Waters, P.J.; McKeon, A.; Leite, M.I. Serologic diagnosis of NMO: A multicenter comparison of aquaporin-4-IgG assays. Neurology 2012, 78, 665-671. [CrossRef] [PubMed]

70. Komorowski, L.; Teegen, B.; Probst, C. Autoantibodies against exocrine pancreas in Crohn's disease are directed against two antigens: The glycoproteins CUZD1 and GP2. J. Crohns Colitis 2013, 7, 780-790. [CrossRef] [PubMed]

71. Hemmilä, I.; Dakubu, S.; Mukkala, V.M.; Siitari, H.; Lövgren, T. Europium as a label in time-resolved immunofluorometric assays. Anal. Biochem. 1984, 137, 335-343. [CrossRef]

72. Soini, E.; Hemmila, I. Flouroimmunoassay: Present status and key problems. Clin. Chem. 1979, 353-362.

73. Zhang, Q.; Huang, B.; Liu, X.; Liu, B.; Zhang, Y.; Zhang, Z.; Hua, J.; Fan, Y.; Hu, L.; Meng, M.; et al. Ultrasensitive Quantitation of Anti-Phospholipase A2 Receptor Antibody as A Diagnostic and Prognostic Indicator of Idiopathic Membranous Nephropathy. Sci. Rep. 2017, 7, 1-7. [CrossRef]

74. Behnert, A.; Fritzler, M.J.; Teng, B.; Zhang, M.; Bollig, F.; Haller, H.; Skoberne, A.; Mahler, M.; Schiffer, M. An Anti-Phospholipase A2Receptor Quantitative Immunoassay and Epitope Analysis in Membranous Nephropathy Reveals Different Antigenic Domains of the Receptor. PLoS ONE 2013, 8, e61669. [CrossRef]

75. Behnert, A.; Schiffer, M.; Müller-Deile, J.; Beck, L.H.; Mahler, M.; Fritzler, M.J. Antiphospholipase A2receptor autoantibodies: A comparison of three different immunoassays for the diagnosis of idiopathic membranous nephropathy. J. Immunol. Res. 2014, 2014, 143274. [CrossRef]

76. Burbelo, P.D.; Lebovitz, E.E.; Notkins, A.L. Luciferase immunoprecipitation systems for measuring antibodies in autoimmune and infectious diseases. Transl. Res. 2015, 165, 325-335. [CrossRef]

77. Ayalon, R.; Beck, L.H., Jr.; Schlumberger, W. Evaluation of Anti-PLA2R1 as Measured by a Novel ELISA in Patients with Idiopathic Membranous Nephropathy a Cohort Study. Am. J. Clin. Pathol. 2014, 142, $29-34$.

78. Dai, H.; Zhang, H.; He, Y. Diagnostic accuracy of PLA2R autoantibodies and glomerular staining for the differentiation of idiopathic and secondary membranous nephropathy: An updated meta-analysis. Sci. Rep. 2015, 5, 8803. [CrossRef] [PubMed]

79. Li, W.Y. Diagnostic test accuracy of Serum anti-PLa2R autoantibodies and Glomerular PLa2R antigen for diagnosing idiopathic membranous Nephropathy: An Updated meta-analysis. Front. Med. 2018, 5, 101. [CrossRef] [PubMed]

80. Liu, Y.; Li, X.; Ma, C.; Wang, P.; Liu, J.; Su, H.; Zhuo, H.; Kong, X.; Xu, D.; Xu, D. Serum anti-PLA2R antibody as a diagnostic biomarker of idiopathic membranous nephropathy: The optimal cut-off value for Chinese patients. Clin. Chim. Acta 2018, 476, 9-14. [CrossRef] [PubMed]

81. Wang, C.H.; Su, P.T.; Du, X.Y.; Kuo, M.W.; Lin, C.Y.; Yang, C.C.; Chan, H.S.; Chang, S.J.; Kuo, C.; Seo, K.; et al. Thrombospondin type I domain containing 7A (THSD7A) mediates endothelial cell migration and tube formation. J. Cell. Physiol. 2010, 222, 685-694. [CrossRef]

82. Sharma, S.G. Tissue staining for THSD7A in glomeruli correlates with serum antibodies in primary membranous nephropathy: A clinicopathological study. Mod. Pathol. 2018, 31, 616. [CrossRef] 
83. Iwakura, T.; Ohashi, N.; Kato, A. Prevalence of enhanced granular expression of thrombospondin type-1 domain-containing 7A in the glomeruli of Japanese patients with idiopathic membranous nephr-opathy. PLoS ONE 2015, 10, e0138841. [CrossRef]

84. Wang, Y.; He, Y.X.; Diao, T.T.; Wei, S.Y.; Qi, W.R.; Wang, C.C.; Song, S.M.; Bi, M.; Li, C.M.; Zhang, C.X.; et al. Urine anti-PLA2R antibody is a novel biomarker of idiopathic membranous nephropathy. Oncotarget 2018, 9 , 67-74. [CrossRef]

85. Pourcine, F.; Dahan, K.; Mihout, F.; Cachanado, M.; Brocheriou, I.; Debiec, H.; Ronco, P. Prognostic value of PLA2R autoimmunity detected by measurement of anti-PLA2R antibodies combined with detection of PLA2R antigen in membranous nephropathy: A single-centre study over 14 years. PLoS ONE 2017, 12, e0173201. [CrossRef]

86. De Vriese, A.S.; Glassock, R.J.; Nath, K.A.; Sethi, S.; Fervenza, F.C. A Proposal for a Serology-Based Approach to Membranous Nephropathy. J. Am. Soc. Nephrol. 2017, 28, 421-430. [CrossRef]

87. Francis, J.M.; Beck LHJr, S.D. Membranous nephropathy: A journey from bench to bedside. Am. J. Kidney Dis. 2011, 616-626. [CrossRef] [PubMed]

88. Debiec, H. Immune response against autoantigen PLA2R is not gambling: Implications for pathophysiology, prognosis and therapy. J. Am. Soc. Nephrol. 2016, 1275-1277. [CrossRef] [PubMed]

89. Qu, Z.; Zhang, M.F.; Cui, Z.; Wang, J.; Wang, M.; Zhang, Y.M.; Wang, F.; Wang, X.; Meng, L.Q.; Cheng, X.Y.; et al. Antibodies against M-type phospholipase A2 receptor may predict treatment response and outcome in membranous nephropathy. Am. J. Nephrol. 2018, 48, 438-446. [CrossRef] [PubMed]

90. Tampoia, M. Definition of a new cut-off for the anti-phospholipase A2 receptor (PLA2R) autoantibody immunoassay in patients affected by idiopathic membranous nephropathy. J. Nephrol. 2018, 31, 899-905. [CrossRef] [PubMed]

91. Wu, X.; Liu, L.; Guo, Y.; Yang, L. Clinical value of a serum anti-PLA2R antibody in the diagnosis and monitoring of primary membranous nephropathy in adults. Int. J. Nephrol. Renovasc. Dis. 2018, 11, 241-247. [CrossRef]

92. Bobart, S.A.; De Vriese, A.S.; Pawar, A.S.; Zand, L.; Sethi, S.; Giesen, C.; Lieske, J.C.; Fervenza, F.C. Noninvasive diagnosis of primary membranous nephropathy using phospholipase A2 receptor antibodies. Kidney Int. 2019, 95, 429-438. [CrossRef]

93. Jullien, P.; Polski, B.S.; Maillard, N.; Thibaudin, D.; Laurent, B.; Ollier, E.; Alamartine, E.; Lambeau, G.; Mariat, C. Anti-phospholipase A2 receptor antibody levels at diagnosis predicts spontaneous remission of idiopathic membranous nephropathy. Clin. Kidney J. 2017, 10, 209-214. [CrossRef]

94. Debiec, H.; Ronco, P. PLA2R autoantibodies and PLA2R glomerular deposits in membranous nephropathy. N. Engl. J. Med. 2011, 364, 689-690. [CrossRef]

95. Hladunewich, M.A.; Cattran, D.; Beck, L.H.; Odutayo, A.; Sethi, S.; Ayalon, R.; Leung, N.R. A pilot study to determine the dose and effectiveness of adrenocortico- trophic hormone (H.P. Acthar ${ }^{\circledR}$ Gel) in ne- phrotic syndrome due to idiopathic membra- nous nephropathy. Nephrol. Dial. Transpl. 2014, 29, 1570-1577. [CrossRef]

96. Dahan, K.; Debiec, H.; Plaisier, E.; Cachanado, M.; Rousseau, A.; Wakselman, L.; Michel, P.-A.; Mihout, F.; Dussol, B.; Matignon, M.; et al. Rituximab for Severe Membranous Nephropathy: A 6-Month Trial with Extended Follow-Up. J. Am. Soc. Nephrol. 2017, 28, 348-358. [CrossRef]

97. Ruggenenti, P.; Debiec, H.; Ruggiero, B.; Chianca, A.; Pelle, T.; Gaspari, F.; Suardi, F.; Gagliardini, E.; Orisio, S.; Benigni, A.; et al. Anti-Phospholipase A2 Receptor Antibody Titer Predicts Post-Rituximab Outcome of Membranous Nephropathy. J. Am. Soc. Nephrol. 2015, 26, 2545-2558. [CrossRef] [PubMed]

98. Beck, L.H.; Fervenza, F.C.; Beck, D.M.; Bonegio, R.G.B.; Malik, F.A.; Erickson, S.B.; Cosio, F.G.; Cattran, D.C.; Salant, D.J. Rituximab-Induced Depletion of Anti-PLA2R Autoantibodies Predicts Response in Membranous Nephropathy. J. Am. Soc. Nephrol. 2011, 22, 1543-1550. [CrossRef] [PubMed]

99. Dahan, K.; Gillion, V.; Johanet, C.; Debiec, H.; Ronco, P. The Role of PLA2R Antibody in Treatment of Membranous Nephropathy. Kidney Int. Rep. 2018, 3, 498-501. [CrossRef] [PubMed]

100. Stohl, W.; Hiepe, F.; Latinis, K.M. Belimumab reduces autoantibodies normalizes low complement levels, and reduces select B cell populations in patients with systemic lupus erythematosus. Arthritis Rheum. 2012, 64, 2328-2337. [CrossRef] [PubMed] 
101. Willcocks, L.; Barrett, C.; Brenchley, P.; Schmidt, T.; Gisbert, S.; Cai, G.; Savage, C. Effect of belimumab on proteinuria and anti-PLA2R autoantibody in idiopathic membranous ne-phropathy-6 months data. Nephrol. Dial. Transpl. 2015, 30, 32-33. [CrossRef]

102. Lv, J.; Hou, W.; Zhou, X. Interaction between PLA2R1 and HLA-DQA1 variants associates with anti-PLA2R antibodies and membranous nephropathy. J. Am. Soc. Nephrol. 2013, 24, 1323-1329. [CrossRef]

103. Oh, Y.J.; Yang, S.H.; Kim, D.K.; Kang, S.W. Autoantibodies against phospholipase A2 receptor in Korean patients with membranous nephropathy. PLoS ONE 2013, 8, e62151. [CrossRef]

104. Bech, A.P.; Hofstra, J.M.; Brenchley, P.E. Association of anti-PLA2R antibodies with outcomes after immunosuppressive therapy in idiopathic membraneous nephropathy. Clin. J. Am. Soc. Nephrol. 2014, 9, 1386-1392. [CrossRef]

105. Hoxha, E.; Thiele, I.; Zahner, G.; Panzer, U.; Harendza, S. Phospholipase A2 receptor autoantibodies and clinical outcome in patients with primary membranous nephropathy. J. Am. Soc. Nephrol. 2014, 25, 1357-1366. [CrossRef]

106. Hoxha, E.; Harendza, S.; Pinnschmidt, H.; Panzer, U. PLA2R antibody level and clinical outcome in patients with membranous nephropathy and non-nephrotic range proteinuria under treatment with inhibitors of the renin-angiotensin system. PLoS ONE 2014, 9, e110681. [CrossRef]

107. Van den Brand, J.A.; Hofstra, J.M.; We, J. Prognostic value of risk score and urinary markers in idiopathic membranous nephropathy. Clin. J. Am. Soc. Nephrol. 2012, 7, 1242-1248. [CrossRef] [PubMed]

108. Cattran, D.C.; Kim, E.D.; Reich, H.; Hladunewich, M.; Kim, S.J. Toronto Glomerulonephritis Registry group, and for the T.G.R. Membranous Nephropathy: Quantifying Remission Duration on Outcome. J. Am. Soc. Nephrol. 2017, 28, 995-1003. [CrossRef] [PubMed]

109. Domingos, M.A.M.; Moreira, S.R.; Gomez, L.; Goulart, A.; Lotufo, P.A.; Benseñor, I.; Titan, S. Urinary Retinol-Binding Protein: Relationship to Renal Function and Cardiovascular Risk Factors in Chronic Kidney Disease. PLoS ONE 2016, 11, e0162782. [CrossRef] [PubMed]

110. Lin, L.; Ming Wang, W.; Xia Pan, X.; Xu, J.; Ni Gao, C.; Zhang, W.; Ren, H.; Yuan Xie, J.; Yan Shen, P.; Wen $\mathrm{Xu}, \mathrm{Y}$;; et al. Biomarkers to detect membranous nephropathy in Chinese patients. Oncotarget 2016, 7, 67868. [CrossRef] [PubMed]

111. Branten, A.J.; du Buf-Vereijken, P.W.; Klasen, I.S.; Bosch, F.H.; Feith, G.W.; Hollander, D.A. Urinary excretion of beta-2 microglobulin and IgG predict prognosis in idiopathic membranous nephropathy: A validation study. J. Am. Soc. Nephrol. 2005, 16, 169-174. [CrossRef] [PubMed]

112. Van den Brand, J.A.; van Dijk, P.R.; Hofstra, J.M. Long-term outcomes in idiopathic membranous nephropathy using a restrictive treatment strategy. J. Am. Soc. Nephrol. 2014, 25, 150-158. [CrossRef]

113. Polanco, N.; Gutiérrez, E.; Covarsí, A. Spontaneous remission of nephrotic syndrome in idiopathic membranous nephropathy. J. Am. Soc. Nephrol. 2010, 21, 697-704. [CrossRef] 